\title{
Settlement of blue crab Callinectes sapidus megalopae in a North Carolina estuary
}

\author{
R. B. Forward Jr. ${ }^{*}$ J. H. Cohen, R. D. Irvine, J. L. Lax, R. Mitchell, A. M. Schick, \\ M. M. Smith, J. M. Thompson, J. I. Venezia
}

Nicholas School of Environment and Earth Sciences, Duke University Marine Laboratory, 135 Duke Marine Lab Road, Beaufort, North Carolina 28516, USA

\begin{abstract}
Nightly settlement of blue crab Callinectes sapidus megalopae on passive collectors was monitored from September to November over $7 \mathrm{yr}$ at a single location in the Newport River estuary (North Carolina, USA). The total number of megalopae settling varied yearly from 1869 to 12007. Megalopal abundance was generally related to commercial landings of adult crabs 2 yr later. Throughout the sampling period, megalopae settled continuously at low levels with episodic peaks. The 6 largest peaks accounted for $>50 \%$ of all settlement in most years. Settlement was not related to along- or across-shore wind stress, but time-series analysis indicated significant periodicity in settlement in all years. In 4 of the years there was a semi-lunar periodicity with settlement occurring at the time of neap tides during the quarter phases of the moon. Detailed analysis of settlement peaks from all years also indicated a relationship to neap tide. The proposed explanation for this relationship is that (1) megalopae undergo flood-tide transport for entrance into estuaries and up-estuary movement, and (2) the behavior underlying flood-tide transport is most effective when all of the nocturnal flood tide occurs in darkness. The latter situation occurred during neap tides at the quarter phases of the moon when the average time of slack water at the end of flood tide occurred after midnight.
\end{abstract}

KEY WORDS: Blue crab $\cdot$ Callinectes sapidus $\cdot$ Megalopae $\cdot$ Settlement $\cdot$ Tide $\cdot$ Wind $\cdot$ Lunar phase

\section{INTRODUCTION}

Most estuarine decapod crustaceans have planktonic larvae that disperse seaward from adult populations (Christy \& Morgan 1998) and develop in coastal/offshore areas. Return to estuaries by the postlarval (megalopal) stage occurs in 2 phases. First, megalopae are transported shoreward to the entrance of estuaries by physical processes such as wind-driven surface currents (e.g. Epifanio \& Garvine 2001), internal waves (e.g. Shanks 1983, 1988, Shanks \& Wright 1987) or shoreward-moving upwelling fronts (Shanks et al. 2000). Second, megalopae undergo flood-tide transport (Christy \& Morgan 1998, Forward \& Tankersley 2001) for movement into and up estuaries. During flood-tide transport (FTT), megalopae are transported in the water column during flood tides and remain on or near the bottom during ebb tides.

The blue crab Callinectes sapidus follows this life cycle, as females undergo a spawning migration in which they release larvae near the mouths of estuaries (e.g. Tankersley et al. 1998). Larvae are transported to coastal areas (e.g. Smyth 1980, McConaugha et al. 1983, Epifanio et al. 1989) where they pass through 7 zoeal stages before molting to the megalopa stage (Costlow \& Bookhout 1959). Shoreward transport of megalopae to inlets of estuaries is usually related to wind-driven Ekman circulation associated with downwelling-favorable wind (reviewed by Epifanio 1995, Epifanio \& Garvine 2001). However, Shanks (1998) found that blue crab megalopae were transported shoreward by tidally driven processes perhaps associ- 
ated with internal waves (Shanks 1988). Megalopae undergo FTT for movement into and up estuaries where they settle in nursery areas of aquatic vegetation (Dittel \& Epifanio 1982, Brookings \& Epifanio 1985, Mense \& Wenner 1989, Little \& Epifanio 1991, De Vries et al. 1994, Olmi 1994).

The conceptual model for the behavior underlying FTT is that blue crab megalopae ascend in response to a continuous rate of increase in salinity (Tankersley et al. 1995) associated with flood tide. Once in the water column, turbulence induces sustained swimming (Welch et al. 1999, Welch \& Forward 2001) and megalopae settle out of the water column when water turbulence declines, around the time of slack water at the end of flood tide and before ebb tide (slack water before ebb; Tankersley et al. 2002). The decrease in salinity during ebb tide inhibits megalopae from entering the water column during this tidal phase (Welch \& Forward 2001). In addition, since light induces negative phototaxis in estuarine water (Forward \& Rittschof 1994), megalopae remain on or near the bottom during the day, and only undergo FTT at night (e.g. De Vries et al. 1994).

Although the mechanism (flood-tide transport) for movement into and up an estuary is known, there is considerable variability in the number of blue crab megalopae entering an estuary between nights. This variability has been quantified along the east coast of the USA by measuring nightly settlement on passive collectors in the Delaware Bay (Jones \& Epifanio 1995, Garvine et al. 1997), York River, Virginia (Goodrich et al. 1989, Olmi et al. 1990, van Monfrans et al. 1990, Metcalf et al. 1995, Olmi 1995), North Carolina (Mense et al. 1995, Shanks 1998), Charleston Harbor, South Carolina (Boylan \& Wenner 1993, Blanton et al. 1995), Sapelo Island, Georgia (Wrona et al. 1995) and the Gulf of Mexico (Perry et al. 1995, Morgan et al. 1996, Hasek \& Rabalais 2001). During larval developmental periods, megalopal settlement is characterized by constant low levels of nightly settlement punctuated by episodic peaks that account for more than $50 \%$ of settlement during a season (reviewed by Rabalais et al. 1995, van Montfrans et al. 1995). Analyses have related the peaks to environmental events such as wind (Goodrich et al. 1989, Blanton et al. 1995, Mense et al. 1995, Olmi 1995, Rabalais et al. 1995 Morgan et al. 1996), lunar phase (Olmi et al. 1990, van Montfrans et al. 1990, 1995, Boylan \& Wenner 1993, Jones \& Epifanio 1995, Mense et al. 1995, Metcalf et al. 1995, Olmi 1995), tidal amplitude (Mense et al. 1995, Olmi 1995, Perry et al. 1995, Rabalais et al. 1995, Morgan et al. 1996) and salinity (Olmi 1995).

Long-term monitoring is useful for determining the relationship between megalopal immigration and environmental factors. Identifying key environmental factors, such as wind events, would allow predictions of yearly recruitment by measuring the environmental factors. Blue crabs enter the fishery 1.5 to $2 \mathrm{yr}$ after megalopal settlement in estuaries (Williams 1984). Since adult abundance depends upon immigration, quantifying recruitment from measurements of environmental factors would allow predictions of the future adult abundance.

The present study was undertaken to determine the settlement pattern of blue crab megalopae in the Newport River estuary (North Carolina, USA) as related to environmental factors. Settlement on passive collectors was monitored from September to November during $7 \mathrm{yr}$, and time-series data were analyzed for periodicity as well as for cross-correlation with tidal amplitude and wind stress. Further analysis examined the relationship between settlement peaks and tidal times, tidal amplitude, and lunar cycle. The magnitude of nightly immigration depends upon the abundance of megalopae at the entrance of an estuary and the success of FTT. Nevertheless, since immigration does not occur without FTT, we hypothesized that settlement peaks would occur on nights when the relationship between the times of flood tide and the light:dark cycle promote maximal FTT. These conditions are predicted to occur when all of the nocturnal flood tide occurs in darkness (Tankersley et al. 2002).

\section{MATERIALS AND METHODS}

Nightly immigration of Callinectes sapidus Rathbun megalopae into an estuary was determined during 7 years (1993 to 1996, 1998, 2000 and 2002) from early September to November (Table 1). These months were

Table 1. Callinectes sapidus. Collection periods and number of megalopae in the 6 largest peaks each year

\begin{tabular}{|lccccc|}
\hline $\begin{array}{l}\text { Yearly } \\
\text { starting } \\
\text { date } \\
\text { (mm/dd/yy) }\end{array}$ & $\begin{array}{c}\text { Collection } \\
\text { period duration } \\
\text { (no. of } \\
\text { nights) }\end{array}$ & $\begin{array}{c}\text { Nights } \\
\text { not } \\
\text { sampled }\end{array}$ & $\begin{array}{c}\text { Total } \\
\text { megalopae } \\
\text { collected }\end{array}$ & $\begin{array}{c}\text { Number } \\
\text { in } 6 \\
\text { largest } \\
\text { peaks }\end{array}$ & $\begin{array}{c}\text { \% of } \\
\text { total in } 6 \\
\text { largest } \\
\text { peaks }\end{array}$ \\
\hline 09/15/1993 & 69 & 8 & 2190 & 1369 & 63.5 \\
09/06/1994 & 71 & 6 & 4457 & 2055 & 46.1 \\
$09 / 13 / 1995$ & 69 & 0 & 9229 & 5038 & 54.6 \\
$09 / 14 / 1996$ & 70 & 4 & 12007 & 8086 & 67.3 \\
$09 / 11 / 1998$ & 76 & 4 & 2259 & 734 & 32.5 \\
$09 / 02 / 2000$ & 73 & 0 & 5273 & 3400 & 64.5 \\
$09 / 12 / 2002$ & 63 & 3 & 1869 & 1007 & 53.9 \\
\hline
\end{tabular}


selected because in this estuary the maximum number of females undergo the spawning migration for larval release between the last week in July and second week in August (R. Tankersley pers. comm.). Since development to the megalopal stage takes ca. 30 to $50 \mathrm{~d}$ (Costlow \& Bookhout 1959), the majority of megalopae were predicted to enter the estuary during the fall months. The total number of nights sampled each year ranged from 60 to 73 . Sampling was almost continuous, and continued until the number of megalopae collected each night declined to near zero.

Nightly immigration was quantified as settlement on passive collectors, consisting of a hog's hair filter material sleeve surrounding an inner plastic cylinder (Metcalf et al. 1995). Three collectors were suspended at a depth of ca. $1 \mathrm{~m}$ below the surface at mean low tide from the dock at Duke University Marine Laboratory. Maintaining a constant depth of the collectors was unnecessary because megalopae are uniformly distributed throughout the water column during nocturnal flood tides at this location (De Vries et al. 1994). In addition, Metcalf et al. (1995) demonstrated that in most cases 3 replicate collectors were adequate to standardize the variance of consecutive collections. The number of megalopae settling on each collector each night was determined by removing the collectors from the water during the day. Megalopae were removed from each sleeve by rinsing with freshwater following the standard protocol outlined by Metcalf et al. (1995). The rinse water was collected and sieved to remove megalopae, which were counted in the laboratory. The total and average numbers of megalopae per collector were calculated for each $24 \mathrm{~h}$ period.

The relationship between megalopal settlement and environmental variables (wind and tides) was analyzed for each year using time series analysis techniques. Gaps in each settlement time series were filled using linear interpolation, and data were $\log _{10}(x+1)$-transformed to minimize the effect of large settlement peaks present each year, primarily during September and early October (Shanks 1998). A seasonal trend of increasing settlement followed by decreasing settlement throughout the fall was removed from each series prior to analysis by smoothing each transformed settlement time series with a $3 \mathrm{~d}$ moving average, then fitting the smoothed series to the transformed data and using the residuals for subsequent analyses. The periodicity in each time series was evaluated using autocorrelation analysis. Autocorrelation plots with peaks exceeding the 95\% confidence interval of $\pm 2 / \sqrt{ } \mathrm{N}$ ( $\mathrm{N}=$ sample size) were considered statistically significant (Chatfield 1989). The period values for time series with statistically significant periodicity were determined using maximum entropy spectral analysis (MESA; Levine et al. 2002).
MESA fits an autoregressive model to the data and uses Fourier analysis of the autoregressive coefficients to construct a spectrum.

The sampling site is ca. $1.5 \mathrm{~km}$ inside the entrance to the Newport River estuary (Beaufort, North Carolina, USA: $34^{\circ} 43^{\prime} \mathrm{N}_{i} 76^{\circ} 40^{\prime} \mathrm{W}$ ). This area experiences semidiurnal tides with maximum amplitudes of ca. $1.15 \mathrm{~m}$ above mean low water. Tidal heights and times were obtained from a tide station (NOAA National Water Level Observation Network) on a dock adjacent to the sampling area. The maximum nocturnal tidal height was determined for each day of megalopal settlement, and used in cross-correlation analysis against the settlement time series. The cross-correlation statistic $(R)$ was calculated for lags of -10 to $10 \mathrm{~d}$ according to Wing et al. (1995). As several of the megalopal settlement time series and all of the tidal time series were autocorrelated (see 'Results', tidal autocorrelation not shown), the $95 \%$ confidence intervals used to evaluate the significance of the cross-correlations at each lag were constructed in 2 ways, one with SEs assuming independent points and the other assuming autocorrelations of the series (Wing et al. 1995). The SE calculation resulting in a more conservative significance criterion was used for calculating $95 \%$ CIs.

Wind data were obtained from the NOAA National Data Buoy Center for Cape Lookout, North Carolina, which is on the coast ca. $10 \mathrm{~km}$ from the sampling site. The speed and direction that the wind blew for the $24 \mathrm{~h}$ before each sampling date were averaged from hourly records starting at 07:00 $\mathrm{h}$ the day before collection and ending at 06:00 $\mathrm{h}$ on the sampling date, such that wind data used in analyses correspond to the approximate times of collector deployment. Prior to calculating along- and across-shore wind stresses (Large \& Pond 1981, Blanton et al. 1989), wind direction was rotated $90^{\circ}$ clockwise to account for the east-west orientation of the coastline in the study region. Wind stress data (dynes $\mathrm{cm}^{-2}$ ) were related to the megalopal settlement time series using cross-correlation analysis. There was a distinct semi-lunar signal apparent in the MESA spectra for 4 of 7 megalopal settlement time series, though this was not always the dominant period (Table 2). These semi-lunar signals could potentially mask the effects of wind on settlement (Shanks 1998). This potential problem was resolved for these years $(1995,1996,2000$ and 2002) by removing the semi-lunar signal from settlement and wind time series using autoregressive integrated moving average (ARIMA) models prior to cross-correlation analysis. The seasonal component of the models was set to the time between spring tides for a given series, and models fit to both the transformed megalopal settlement data and the wind stress data (Shanks 1998). Model selection was done using standard techniques de- 
Table 2. Callinectes sapidus. Time series analysis of megalopal settlement and environmental parameters. Periodicities of residuals from the moving average fit of log-transformed megalopal settlement time series were determined using autocorrelation analysis. For years with significant periodicity $\left({ }^{*} p<0.05\right)$, maximum entropy spectral analysis $(\mathrm{MESA})$ was used to calculate the period value. Lesser semi-lunar periodicities, if present, are included in parentheses. Significant cross-correlations $(p<0.05)$ between megalopal settlement and environmental parameters are reported as days by which the environmental parameters lead settlement, with corresponding cross-correlation R-values in parentheses. For years with a tidal periodicity in megalopal settlement (1995, 1996, 2000 and 2002), residuals from autoregressive integrated moving average (ARIMA) models were used in the cross-correlation of megalopal settlement and wind stress in order to remove the potentially confounding effect of tidal periodicity. $\mathrm{ns}=$ not significant; $\mathrm{d}=$ days

\begin{tabular}{|c|c|c|c|c|c|}
\hline \multirow[t]{2}{*}{ Year } & \multicolumn{2}{|c|}{ Settlement periodicity } & \multicolumn{3}{|c|}{ Cross-correlation with settlement } \\
\hline & $\begin{array}{l}\text { Autocorrelation } \\
\text { significance }\end{array}$ & $\begin{array}{l}\text { MESA period } \\
\text { (d) }\end{array}$ & $\begin{array}{l}\text { Maximum nocturnal } \\
\text { tidal height }\end{array}$ & $\begin{array}{l}\text { Along-shore } \\
\text { wind stress }\end{array}$ & $\begin{array}{l}\text { Across-shore } \\
\text { wind stress }\end{array}$ \\
\hline 1993 & * & 5.5 & ns & ns & ns \\
\hline 1994 & * & 5.3 & ns & $-6 \mathrm{~d}(-0.294)$ & $0 \mathrm{~d}(-0.373)$ \\
\hline 1995 & * & 14.2 & $\begin{array}{c}-8 \mathrm{~d}(0.382) \\
0 \mathrm{~d}(-0.406) \\
7 \mathrm{~d}(0.393)\end{array}$ & $-1 \mathrm{~d}(-0.434)$ & ns \\
\hline 1996 & * & $3.8(16.7)$ & $-1 \mathrm{~d}(-0.247)$ & $\begin{array}{l}-4 \mathrm{~d}(0.442) \\
-2 \mathrm{~d}(-0.459)\end{array}$ & $-3 \mathrm{~d}(0.626)$ \\
\hline 1998 & * & 5.7 & ns & ns & $-10 \mathrm{~d}(-0.527)$ \\
\hline 2000 & * & 14.7 & $\begin{array}{c}-8 \mathrm{~d}(0.344) \\
-2 \mathrm{~d}(-0.521) \\
4 \mathrm{~d}(0.381)\end{array}$ & $\begin{array}{l}-8 \mathrm{~d}(-0.525) \\
-2 \mathrm{~d}(0.666)\end{array}$ & $-10 \mathrm{~d}(0.552)$ \\
\hline 2002 & * & $5.5(14.4)$ & $\begin{array}{l}-9 \mathrm{~d}(0.368) \\
-1 \mathrm{~d}(-0.280)\end{array}$ & ns & ns \\
\hline
\end{tabular}

scribed in Venables \& Ripley (1999). The residuals from the best-fitting ARIMA model for each settlement series were cross-correlated with residuals from ARIMA models fit to both along- and across-shore wind stress.

As dramatic peaks in settlement occurred each fall, we also determined the relationship between the dates for the 6 largest number of megalopal settlement peaks each year and tidal variables. Six peaks were selected for analysis because they represented the minimal number of peaks when $>50 \%$ of the megalopae were collected during most years. Since the greatest number of megalopae settled during September and early October, this analysis was primarily limited to the $5 \mathrm{wk}$ interval from September 7 to October 14 (2 exceptions). The justifications for focusing on this time period were that there were 7 replicate data sets (42 data points), which would reduce any bias due to a single year, the magnitude of the peaks clearly distinguished them from low-level daily settlement, and analyzing these peaks would address the central hypothesis. Since megalopal settlement occurs in pulses lasting several days, groups of peaks tended to occur sequentially. We acknowledge that some of these peaks may not be independent measures of megalopal settlement, but have included their analysis to reinforce the conclusion from the time series analysis.
Inter-annual differences in settlement were determined using Kruskal-Wallis ANOVA on ranks (Zar 1999). Settlement peaks were related to the time of nocturnal slack water before ebb, determined from tidal current speeds at a location ca. $0.1 \mathrm{~km}$ away from the megalopae sampling site. Peaks were related to the time of slack water before ebb tide at night because, during flood-tide transport, megalopae settle out of the water column on the collectors at this time (Tankersley et al. 2002). The proportion of settlement peaks occurring on different phases of the tide were compared by calculating a Z-statistic (Walpole 1974).

An additional consideration was the relationship between the total number of megalopae collected and subsequent commercial landings of adult blue crabs. Yearly commercial landings of hard crabs and the number of fishing trips were obtained from the North Carolina Division of Marine Fisheries. Landings data were adjusted for fishing effort by calculating the weight of crabs landed per trip $\left(\mathrm{kg} \mathrm{trip}^{-1}\right)$. Since blue crabs enter the fishery from 1.5 to 2 yr after settlement in an estuary (Williams 1984), the total number of megalopae collected each year was related to crab landings per trip 2 yr later, for both the local estuarine areas (Bogue Sound, Core Sound, Newport River and North River, North Carolina) and for the entire state of North Carolina. 


\section{RESULTS}

\section{Yearly settlement patterns}

Megalopal settlement on collectors consisted of periods with few settlers punctuated by very large peaks (Figs. 1 \& 2). The total number of megalopae collected varied dramatically from year to year (Table $1 ; H_{6}=$ 25.52, p < 0.001, ANOVA on ranks) ranging from 1869 in 2002 to 12007 in 1996. The largest peak occurred on October 8, 1996 (Fig. 2), when the average number of

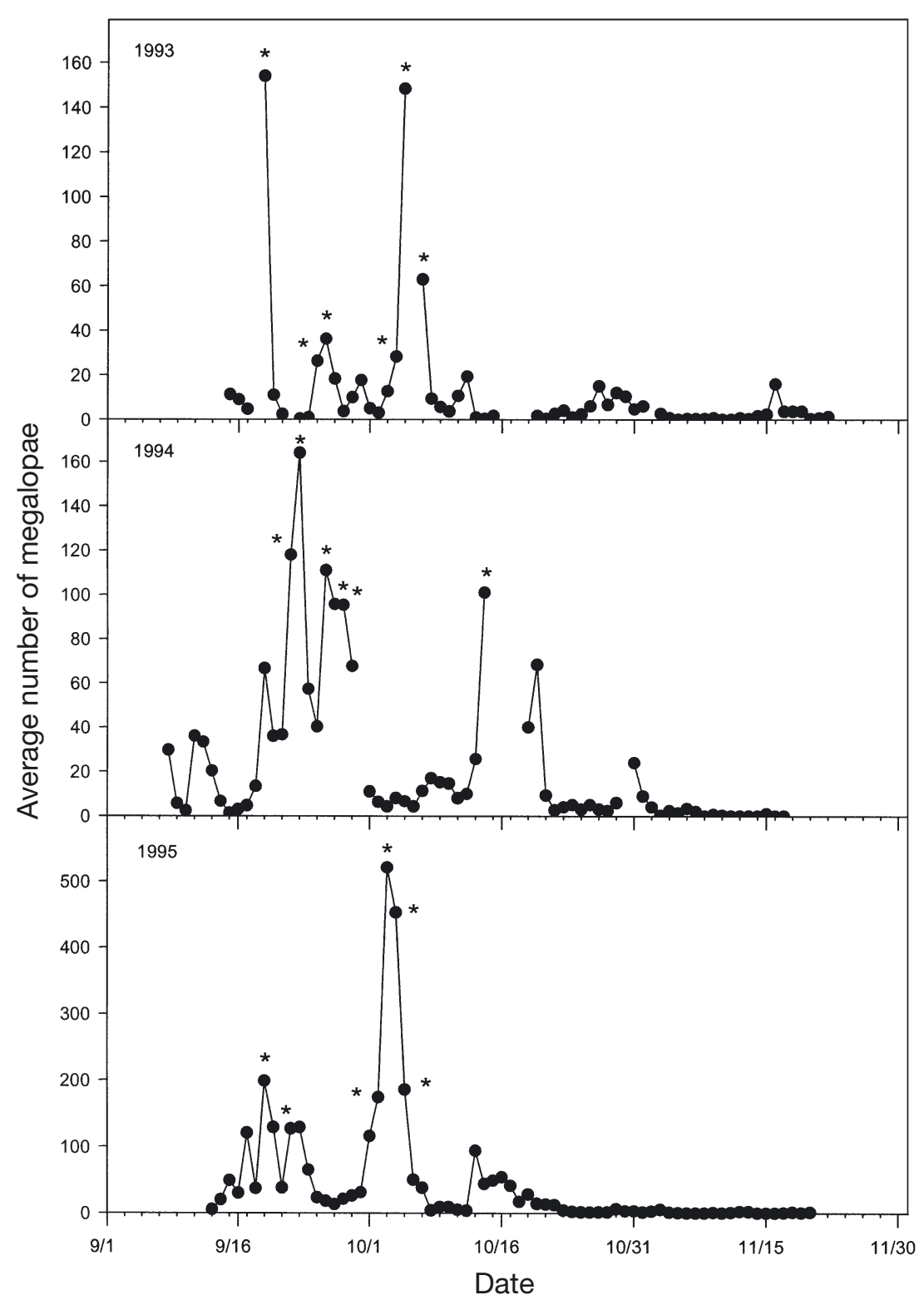

Fig. 1. Callinectes sapidus. Average number of megalopae $(\mathrm{n}=3)$ settling on collectors each night during 1993, 1994 and 1995. Gaps in the data indicate nights when collection did not occur. The 6 nights with the highest number of megalopae are indicated by asterisks megalopae per collector was 1587 . The nights with the 6 largest numbers of megalopae (peaks) accounted for 32.5 (1998) to $67.3 \%$ (1996) of all megalopae collected during the sampling period (Table 1), and consistently occurred during September and October (1 exception). During most years, more than $50 \%$ of the megalopae collected occurred during the 6 peaks, and there was no difference among years in the percentage of total megalopae settling during the peaks $\left(H_{6}=4.21, \mathrm{p}=\right.$ 0.648 , ANOVA on ranks). Since the 6 nights only made up ca. $9 \%$ of the total sampling interval, it is clear that the majority of megalopae arrive as pulses on particular nights.

\section{Settlement time series as related to nocturnal tidal height and wind stress}

Autocorrelation analysis of residuals from the moving average fit of the log-transformed megalopal settlement time series indicated significant periodicity $(\mathrm{p}<0.05)$ in all years (Table 2$)$. Semi-lunar periods $(\sim 14.7$ d) were dominant in 2 of those years (1995 and 2000; Table 2). The dominant MESAperiod estimates for all other years were ca. $5.5 \mathrm{~d}$ (Table 2), with lesser semi-lunar periodicities present in 2 other years (1996 and 2002; Table 2).

Cross-correlations of megalopal settlement with maximum nocturnal tidal height were significant for all years that had semi-lunar periodicity, as indicated by MESA (1995, 1996, 2000 and 2002; Table 2). Cross-correlation lags are the days by which the environmental variable leads megalopal settlement. A positive cross-correlation $R$-value for a given lag indicates a positive relationship between the 2 variables at that lag, while a negative $R$-value indicates a negative relationship. In the 4 years that megalopal settlement was significantly cross-correlated with maximum nocturnal tidal height $(1995,1996,2000$ and 2002), negative cross-correlations occurred at lags around spring tides (lags $=-2,-1$ and $0 \mathrm{~d}$ ), while positive cross-correlations were present at lags around neap tides (lags $=-9,-8,4$ and $7 d_{i}$ Table 2). For years in which a semilunar periodicity was not indicated by MESA (1993, 1994 and 1998), no significant cross-correlations between settle- 
ment and maximum nocturnal tidal height were observed (Table 2).

In contrast to the tidal series, no consistent trends in cross-correlation were apparent between megalopal settlement and either along- or across-shore wind stress (Table 2). Positive cross-correlations were found between settlement and along-shore wind stress in 2 of $7 \mathrm{yr}$, with high wind stress preceding high settlement by 4 d in 1996 and by 2 d in 2000. Negative crosscorrelations of settlement with along-shore wind stress were found at lags of either a week ( 6 and $8 \mathrm{~d}$ ) or a couple of days (1 and 2 d) in 4 years $(1994,1995,1996$ and 2000). Positive cross-correlations were found between megalopal settlement and across-shore wind

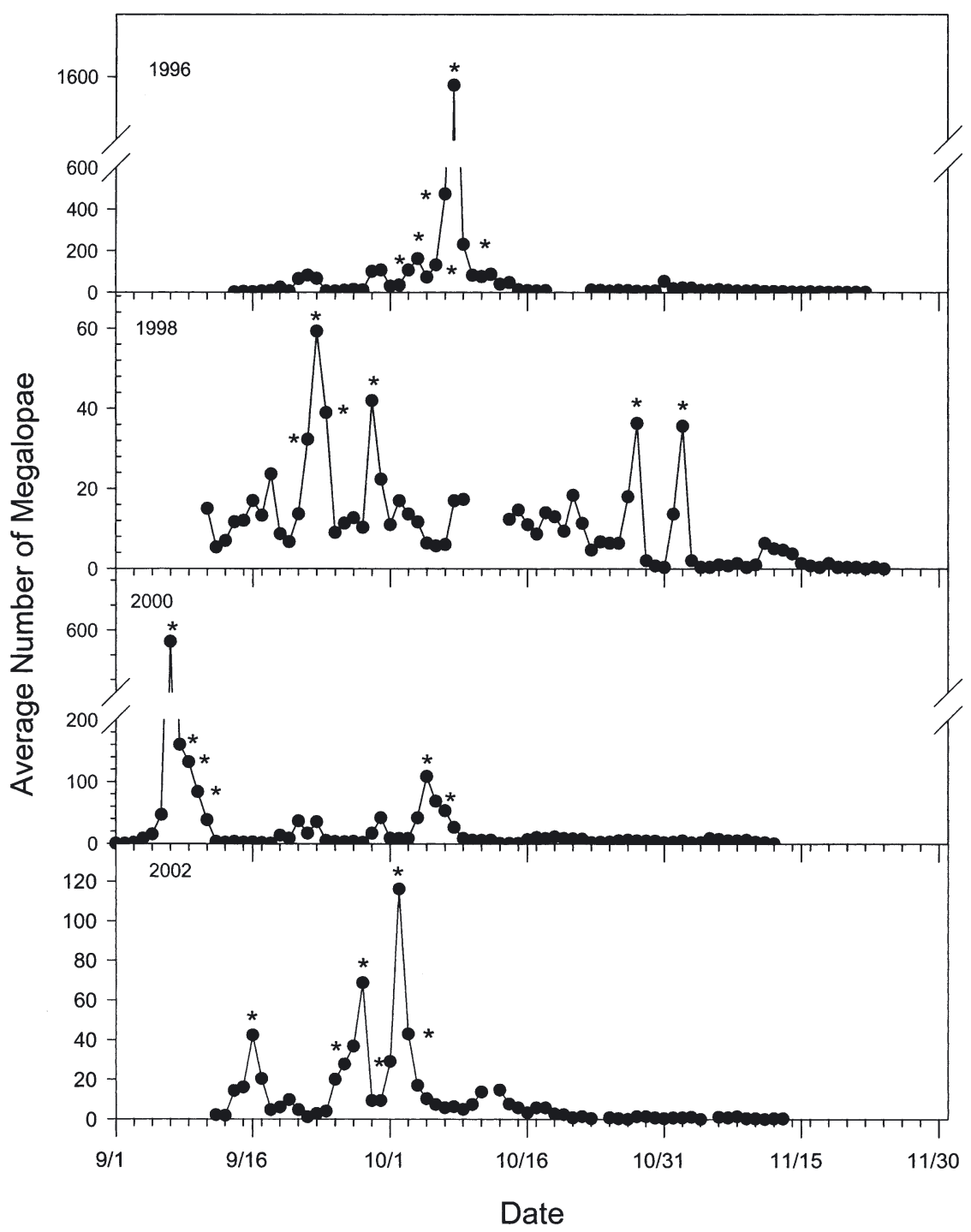

Fig. 2. Callinectes sapidus. Average number of megalopae $(\mathrm{n}=3)$ settling on collectors each night during 1996, 1998, 2000 and 2002. Gaps in the data indicate nights when collection did not occur. The 6 nights with the highest number of megalopae are indicated by asterisks stress in 1996 and 2000, with high wind stress advanced from high settlement by 3 and $10 \mathrm{~d}$, respectively (Table 2). Negative crosscorrelations were observed with a 0 d lag in 1994 and a 10 d lag in 1998.

\section{Nights of maximum settlement (peaks) as related to tides and lunar phase}

The majority of the nights having maximum settlement occurred when the height of nocturnal high tides was low (Fig. 3). Tidal heights were very consistent during September and October from year to year, as the average height of nocturnal high tides at the quarter phases of the moon (neap tides) was $90.2 \mathrm{~cm}(\mathrm{SD}=3.4 \mathrm{~cm} ; \mathrm{n}=28)$ and $113.1 \mathrm{~cm}(\mathrm{SD}=7.8 \mathrm{~cm} ; \mathrm{n}=28)$ at the new and full moons (spring tides). The proportion of peak nights occurring when tidal heights were within $1 \mathrm{SD}$ of the average neap tide height (17/42) was significantly greater than the proportion of peak nights occurring when tidal heights were within $1 \mathrm{SD}$ of the average height during spring tides (5/42; $Z=2.972, p=0.003, Z$-test).

The timing of spring tides at the new and full moon and neap tides at the quarter phases of the moon were also very consistent from year to year. The average time of nocturnal slack water before ebb tide during September and October at the new and full moon during the sampling years was 21:29 $\mathrm{h}$ ( $\mathrm{SD}=10 \mathrm{~min} ; \mathrm{n}=28$ ) and at the quarter phases was $03: 10 \mathrm{~h}(\mathrm{SD}=25 \min \mathrm{n}=$ 28).

If the number of peaks is plotted against time of nocturnal slack water before ebb tide at the time of the peaks, most peaks occurred when nocturnal slack water occurred in the latter half of the night (Fig. 4). The average times of sunset and sunrise during September and October during the sampling years were 19:00 and 07:00 h, respectively. A significantly greater proportion $(30 / 42 ; Z=3.93$, p < $0.001, Z$-test) of the peaks occurred when nocturnal slack water before ebb was in the last $6 \mathrm{~h}$ (01:00 to 07:00 h) of the night as compared to the proportion $(12 / 42)$ when this took place during the first $6 \mathrm{~h}$ of the night (19:00 to 01:00 h). 
The foregoing relationships suggest that the majority of settlement occurred around the quarter phases of the moon, which is evident in Fig. 5. A significantly greater proportion (30/42) of the peaks occurred within $\pm 3 \mathrm{~d}$ of the quarter phases of the moon as compared to the proportion (11/42) of peaks within $\pm 3 \mathrm{~d}$ of the new and full moon $(Z=4.162, \mathrm{p}<0.001, Z$-test $)$.

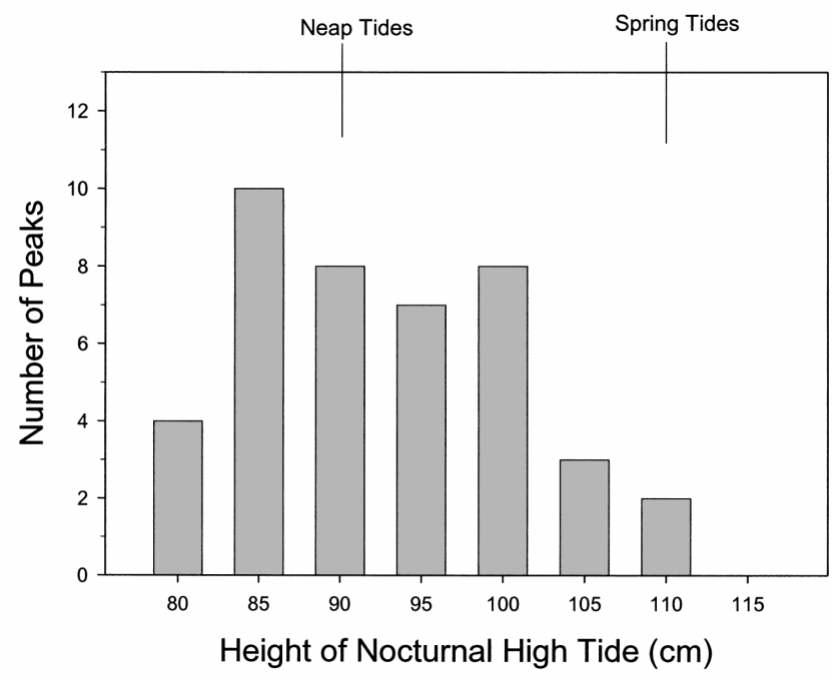

Fig. 3. Callinectes sapidus. Number of peaks versus height above mean low water of the nocturnal high tide on the nights of collection. Tidal heights are grouped into $5 \mathrm{~cm}$ blocks. For example, peaks occurring when nocturnal high tides ranged from 80 to $85 \mathrm{~cm}$ are plotted at $80 \mathrm{~cm}$. Average heights of neap and spring tides are shown by vertical lines

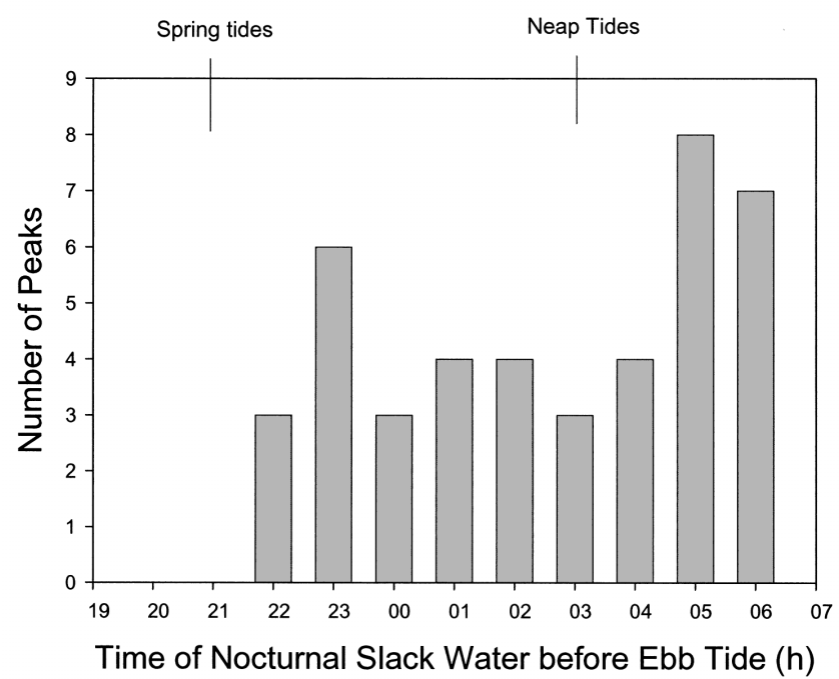

Fig. 4. Callinectes sapidus. Number of peaks that occur with nocturnal slack water before ebb tide at different times of the night. Times are grouped for each hour. For example, $21 \mathrm{~h}$ shows the number of peaks between 21:00 and 22:00 h. Vertical lines indicate average times of nocturnal slack water before ebb tide at the new/full moon (spring tides) and quarter phases of the moon (neap tides)

\section{Settlement versus blue crab harvest}

When the total number of megalopae collected each year is plotted against commercial hard crab landings 2 yr later for either a local estuarine area (Fig. 6A) or the entire state of North Carolina (Fig. 6B), a positive linear relationship is apparent. Although the relationships are not significant because of 1 outlier (1994 settlement and 1996 landings), crab landings generally increased as the total number of megalopae collected 2 yr prior increased.

\section{DISCUSSION}

Blue crab larvae undergo development in offshore areas and are transported as megalopae back to the entrance of estuaries by surface currents (e.g. Epifanio \& Garvine 2001), internal waves (e.g. Shanks 1983) or frontal movements (Shanks et al. 2000). Since tidal currents are usually an order of magnitude greater than megalopal swimming speeds (Luckenbach \& Orth 1992), megalopae cannot swim upstream in an estuary during ebb tide. Thus, they undergo nocturnal flood tide transport (FTT), during which they are carried by flood currents into and up estuaries to nursery areas (Dittel \& Epifanio 1982, Brookings \& Epifanio 1985, Mense \& Wenner 1989, Little \& Epifanio 1991, De Vries et al. 1994, Olmi 1994). FTT is commonly used by invertebrates and fishes for estuary immigration, even by species that can swim against ebb-tide currents (e.g.

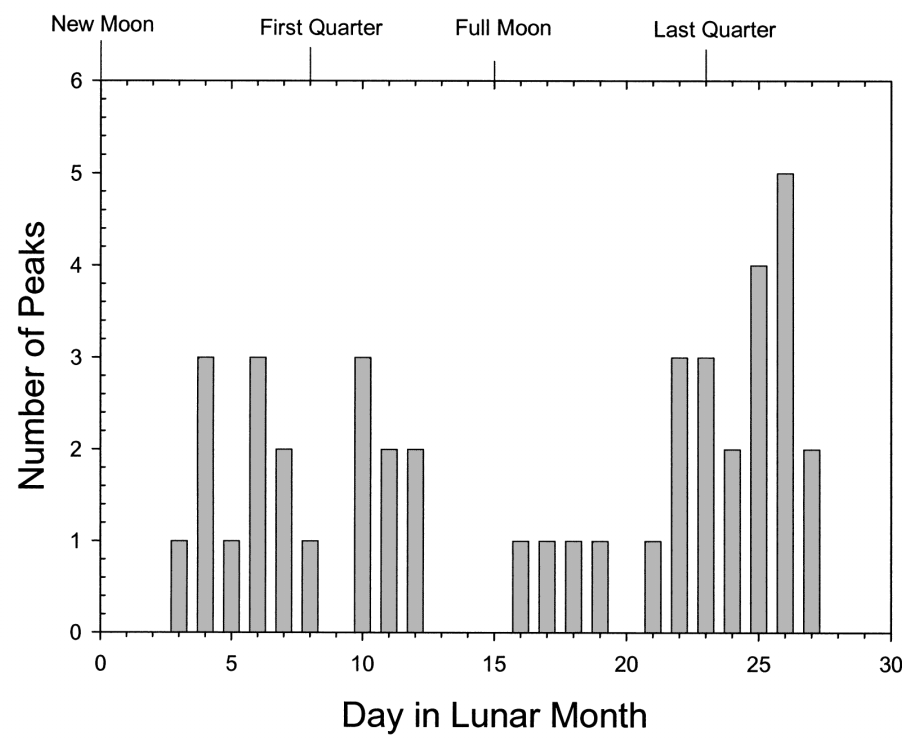

Fig. 5. Callinectes sapidus. Number of peaks in megalopal settlement versus day in the lunar month. Lunar phases are shown at the top of the figure beginning with the new moon 


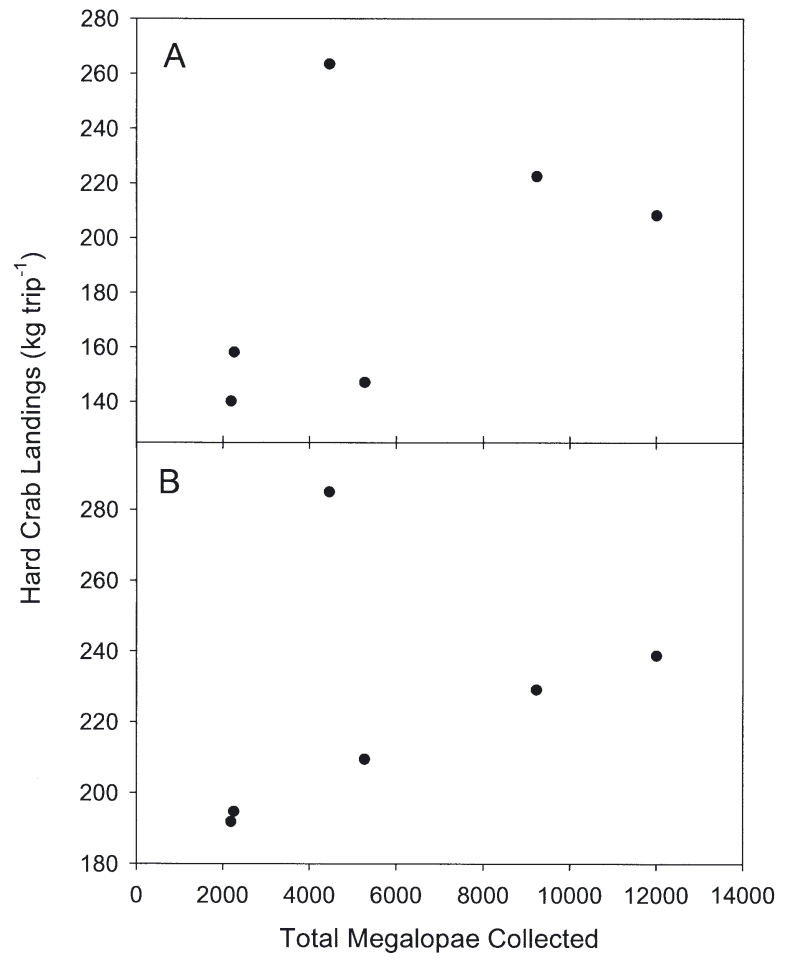

Fig. 6. Callinectes sapidus. Relationship between total number of megalopae collected in all years shown in Table 1, except 2002, and (A) commercial crab-pot landings (kg trip ${ }^{-1}$ ) of hard blue crabs 2 yr later as reported by the North Carolina Division of Marine Fisheries for waters near the megalopae collection site (Bogue Sound, Core Sound, Newport River, North River), and (B) total North Carolina commercial crabpot landings

Stasko 1975), and transport most often occurs at night (Forward \& Tankersley 2001).

The present study quantified immigration of blue crab megalopae into the Newport River estuary by monitoring settlement on collectors from September to November during 7 years. Maximum megalopal immigration into the estuary was predicted to occur during these months because the peak in the number of females undergoing the seaward spawning migration occurred earlier, from late July to early August in this estuary (R. Tankersley pers. comm.). The sampling site was located ca. $1.5 \mathrm{~km}$ from the inlet of the estuary (Beaufort Inlet). A previous study near the study site found that the majority (97 to $98 \%$ ) of megalopae settling on passive collectors were in intermolt (Tankersley et al. 2002). Since chemical cues in estuarine water induce the morphological changes leading to premolt and metamorphosis (e.g. Forward et al. 1996), settlement at this site reflected nightly immigration into the estuary.

The general pattern of settlement consisted of continuous low levels punctuated by dramatic peaks that usually accounted for more than $50 \%$ of all settlement (Table 1). This pattern is similar to that observed in other studies along the east coast (e.g. Van Montfrans et al. 1995). Settlement peaks occurred during September and October, and the number of settling megalopae declined to near zero in November (Figs. $1 \& 2$ ). A similar monthly settlement pattern was observed by Shanks (1998) at a North Carolina coastal site, and Mense et al. (1995) in North Carolina estuaries.

The total number of megalopae collected during a season varied an order of magnitude, from 1869 in 2002 to 12007 in 1996. Megalopae grow to mature crabs and enter the fishery ca. 1.5 to $2 \mathrm{yr}$ later (Williams 1984). If the number of megalopae settling in the Newport River estuary reflects settlement in North Carolina estuaries, then yearly total settlement can be related to commercial harvests of blue crabs 2 yr later (Fig. 6). When landings data are corrected for variable fishing effort among years by calculating weight of hard crabs landed per trip, there was no significant linear relationship between landings/trip and total number of megalopae (Fig. 6). However, the general trend was that landings increased as megalopae increased. A similar relationship was observed by Lipcius \& Stockhousen (2002) between megalopal abundance and female spawning stock 1 to 2 yr later in the Chesapeake Bay.

The variability in total number of settlers between years could be related to the number of spawning females (Lipcius \& Stockhausen 2002) and/or environmental events that transport megalopae from coastal development areas to estuary inlets. Since megalopae occur near the surface in offshore areas (e.g. Smyth 1980, McConaugha et al. 1983), wind events greatly affect onshore transport (Epifanio 1995, Epifanio \& Garvine 2001). Megalopal settlement in estuaries has been related to wind events in a number of studies (Goodrich et al. 1989, Blanton et al. 1995, Mense et al. 1995, Olmi 1995, Rabalais et al. 1995, Morgan et al. 1996). Specifically in a North Carolina estuary, Mense et al. (1995) found settlement was related to wind direction, as greater settlement occurred when winds were from the northeast. Pietrafesa et al. (1986) found that northeast winds pile up water against east-facing beaches of North Carolina due to Ekman transport. However, Shanks (1998) did not find a relationship between wind stress and megalopal abundance at a North Carolina coastal site, which suggests that shoreward transport to this site is not influenced by wind events.

In the present study, the lack of consistent crosscorrelations between megalopal settlement and alongand across-shore wind stress suggests a limited role for wind events in forcing larval settlement in the Newport River estuary. The 2 years with positive cross- 
correlations between settlement and along-shore wind stress (1996 and 2000) are consistent with Ekman circulation transporting megalopae shoreward (e.g. Epifanio 1995, Epifanio \& Garvine 2001; Table 2). There is only weak evidence in the cross-correlations between settlement and across-shore wind stress that megalopae are being transported into the estuary by onshore winds, as was observed by Morgan et al. (1996). Only in 1 year (1996, 3 d lag) was the crosscorrelation positive and at a short lag with respect to settlement.

Since tidal times along the east coast of the US vary little from Delaware to South Carolina, the relationship between the times of nocturnal slack water before ebb tide during spring and neap tides are similar to those observed at the present study site (Fig. 4). Neap tides occur during the quarter phases (waxing and waning) of the moon, whereas spring tides occur around the new and full moon. Shanks (1998) found that megalopal abundance at a North Carolina coastal site varied on a semi-lunar cycle, with greatest numbers collected at or just after spring tides. His results agree with those of Mense et al. (1995), who found peak settlement of megalopae in the Banks Channel at Wilmington, North Carolina, occurred around the new moon in 1990 and 1992 and full moon in 1991.

In contrast, Boylan \& Wenner (1993) found that peak settlement in Charleston Harbor, South Carolina, occurred during neap tides at the quarter phases of the moon. Similarly, settlement peaks in the York River, Virginia, did not occur at the new or full moon, but rather in the time interval leading up to the quarter phases of the moon. From 1984 to 1988, van Montfrans et al. (1990) found that peak settlement in the York River occurred in the $7 \mathrm{~d}$ interval after the full moon. Continuing this study, Metcalf et al. (1995) found that from 1989 to 1992, peak settlement occurred 3 to $5 \mathrm{~d}$ after the new and full moon, and continued through the quarter phases of the moon. In addition, settlement covaried with the duration of nocturnal flood tide. Alternatively, Jones \& Epifanio (1995) did not find a relationship between settlement peaks and lunar phase in the Delaware Bay.

Time series analysis of megalopal settlement and maximum nocturnal tidal height in the present study indicated that megalopal settlement occurred at the time of nocturnal neap tides. Four of the settlement time series (1995, 1996, 2000 and 2002) had semi-lunar period lengths of $\sim 14.7 \mathrm{~d}$ (Table 2). Cross-correlations of these series with maximum nocturnal tidal height were positive during neap tides (lag about -7 and $7 \mathrm{~d}$ ) and negative during spring tides (lags about $0 \mathrm{~d}$ ). This relationship suggests that for these years, high megalopal settlement occurs approximately $7 \mathrm{~d}$ before and after maximum nocturnal tidal height (i.e. during noc- turnal neap tides), and low megalopal settlement occurs when nocturnal tidal height is greatest (i.e. during nocturnal spring tides). These results are similar to those for Charleston Harbor (Boylan \& Wenner 1993) and York River (van Montfrans et al. 1990, Metcalf et al. 1995) but not for an estuary at Wilmington, North Carolina (Mense et al. 1995).

Since regional processes affect settlement (van Montfrans et al. 1995), a consideration of the behavioral basis of FTT and time of nocturnal flood tide during the lunar month at the study site provides an explanation for the lunar relationship. In the conceptual model for FTT, megalopae ascend into the water column in response to a rate of salinity increase (Tankersley et al. 1995), remain swimming in response to water turbulence (Welch et al. 1999, Welch \& Forward 2001) and settle out of the water column (e.g. onto collectors) in response to the decrease in turbulence at slack water at the end of flood tide (Tankersley et al. 2002). Since light induces negative phototaxis in estuarine water (Forward \& Rittschof 1994), FTT is inhibited during the day. Thus, immigration into an estuary and up-estuary transport only occurs during intervals when the tide is flooding in darkness. If flood tide begins before sunset or ends after sunrise, megalopae begin FTT after sunset and end it at sunrise, respectively (e.g. Tankersley et al. 2002). In addition, detailed studies indicate transport does not go on over the entire flood tide, but rather begins about midway through flood tide (e.g. De Vries et al. 1994), when rates of salinity increase and turbulence levels are sufficient for FTT (Tankersley et al. 2002).

Thus, considering the behavior underlying FTT, the test hypothesis was that settlement peaks would occur on nights when the relationship between the time of flood tide and the light:dark cycle promotes maximal FTT. To evaluate this hypothesis, it is possible to predict transport patterns depending upon the time of flood tide at night. If slack water before ebb tide occurs shortly after sunset, then there would be a very short time interval during which megalopae could undergo FTT, which predicts few megalopae would be transported short distances. As the time of slack water before ebb tide occurs later in the night (i.e. neap tides), the time interval for transport during flood tide becomes longer and more megalopae can potentially undergo FTT. Finally, FTT is reduced as the time of slack before ebb tide occurs after sunrise because transport stops at sunrise and few megalopae undergo FTT early in flood tides.

This behavioral pattern predicts that at the study site, the greatest numbers of megalopae will undergo FTT into the estuary during neap tides, because at the quarter phases of the moon the average time of nocturnal slack water before ebb was 03:10 $\mathrm{h}$, and the longest 
interval of nocturnal flood tide occurs around this time of the lunar month. Although this prediction is supported by the present study, an additional consideration is megalopal abundance. Two events need to be in place for a peak in megalopal settlement to occur. First, a large number of megalopae must be transported from coastal/offshore areas to the seaward vicinity of an estuarine inlet. Second, the entire flood tide should occur in darkness. If megalopal abundance is low, then few megalopae will be transported into the estuary, regardless of tidal times. This situation was evident in the present study, because settlement peaks did not occur at regular intervals at every quarter phase of the moon each year (Figs. $1 \& 2$; Table 2). Alternatively, if abundance of megalopae is high outside the inlet, but the time of nocturnal flood tides reduces potential FTT, then few megalopae will enter the estuary.

These considerations lead to a variety of scenarios for transport, based on the interrelationship between seaward abundance of megalopae and time of nocturnal flood tide, which could be verified by monitoring abundance of megalopae at an estuary inlet and settlement in the estuary. Nevertheless, the present study does support the general concepts by demonstrating that settlement during several years had a clear positive cross-correlation with neap tides (Table 2). In addition, when settlement peaks from all years are examined, it is apparent that settlement increased as the time of nocturnal slack water before ebb tide occurred later in the night (Fig. 4) and then declined as times occurred near sunrise. Thus, the test hypothesis was supported, as settlement increased at times that were optimal for nocturnal FTT.

Acknowledgements. This study is based on research supported by the National Science Foundation Grants No. OCE9819355 and OCE-0095092. We thank L. Sabo (NCDMF) for providing blue crab landings and trip data, and Drs. J. Hench for assistance with the wind analyses and A. Shanks for helpful comments on the time series analyses.

\section{LITERATURE CITED}

Blanton JO, Amft JA, Lee DK, Riordan A (1989) Wind stress and heat fluxes observed during winter and spring 1986. J Geophys Res 94:10686-10698

Blanton J, Wenner E, Werner F, Knott D (1995) Effects of wind-generated coastal currents on the transport of blue crab megalopae on a shallow continental shelf. Bull Mar Sci 57:739-752

Boylan JM, Wenner EL (1993) Settlement of brachyuran megalopae in a South Carolina, USA, estuary. Mar Ecol Prog Ser 97:237-246

Brookings KG, Epifanio CE (1985) Abundance of brachyuran larvae in a small coastal inlet over six consecutive tidal cycles. Estuaries 8:60-67

Chatfield C (1989) The analysis of time series: an introduction. Chapman \& Hall, New York
Christy JH, Morgan SG (1998) Estuarine immigration by crab postlarvae: mechanisms, reliability and adaptive significance. Mar Ecol Prog Ser 174:51-65

Costlow JD, Bookhout CG (1959) The larval development of Callinectes sapidus Rathbun reared in the laboratory. Biol Bull (Woods Hole) 116:373-396

De Vries MC, Tankersley RA, Forward RB Jr, Kirby Smith WW, Luettich RA Jr (1994) Abundance of estuarine crab larvae is associated with tidal hydrological variables. Mar Biol 118:403-411

Dittel AI, Epifanio CE (1982) Seasonal abundance and vertical distribution of crab larvae in Delaware Bay, USA. Estuaries 5:197-202

Epifanio CE (1995) Transport of blue crab (Callinectes sapidus) larvae in waters off the mid-Atlantic states. Bull Mar Sci 57:713-725

Epifanio CE, Garvine RW (2001) Larval transport on the Atlantic Continental Shelf of North America: a review. Estuar Coast Shelf Sci 52:51-77

Epifanio CE, Masse AK, Garvine RW (1989) Transport of blue crab larvae by surface currents off Delaware Bay, USA. Mar Ecol Prog Ser 54:35-41

Forward RB Jr, Rittschof D (1994) Photoresponses of crab larvae in offshore and estuarine waters: implications for transport. J Exp Mar Biol Ecol 182:183-192

Forward RB Jr, Tankersley RA (2001) Selective tidal-stream transport of marine animals. Oceanogr Mar Biol Annu Rev 39:305-353

Forward RB Jr, De Vries MC, Rittschof D, Frankel DAZ, Bischoff JP, Fisher CM, Welch JM (1996) Effects of environmental cues on metamorphosis of the blue crab Callinectes sapidus. Mar Ecol Prog Ser 131:165-177

Garvine RW, Epifanio CE, Epifanio CC, Wong KC (1997) Transport and recruitment of blue crab larvae: a model with advection and mortality. Estuar Coast Shelf Sci 45: 99-111

Goodrich DM, van Montfrans J, Orth RJ (1989) Blue crab megalopal influx to Chesapeake Bay: evidence for a winddriven mechanism. Estuar Coast Shelf Sci 29:247-260

Hasek BE, Rabalais NN (2001) A comparison of molt states of blue crab megalopae, Callinectes sapidus (Rathbun), sampled with artificial collectors and plankton nets. J Exp Mar Biol Ecol 265:15-27

Jones MB, Epifanio CE (1995) Settlement of brachyuran megalopae in Delaware Bay: an analysis of time series data. Mar Ecol Prog Ser 125:67-76

Large WG, Pond S (1981) Open ocean momentum flux measurements in moderate to strong winds. J Phys Oceanogr 11:324-336

Levine J, Funes P, Dowse H, Hall J (2002) Signal analysis of behavioral and molecular cycles. BMC Neurosci 3: $1-25$

Lipcius RN, Stockhausen WT (2002) Concurrent decline of spawning stock, recruitment, larval abundance, and size of the blue crab Callinectes sapidus in Chesapeake Bay. Mar Ecol Prog Ser 226:45-61

Little KT, Epifanio CE (1991) Mechanism for the re-invasion of the estuary by two species of brachyuran megalopae. Mar Ecol Prog Ser 68:235-242

Luckenback MW, Orth RJ (1992) Swimming velocities and behavior of blue crab (Callinectes sapidus Rathbun) megalopae in still and flowing water. Estuaries 15:186-192

McConaugha JR, Johnson DF, Provenzano AJ, Maris RC (1983) Seasonal distribution of larvae of Callinectes sapidus (Crustacea: Decapoda) in the waters adjacent to Chesapeake Bay. J Crustac Biol 3:582-591

Mense DJ, Wenner EL (1989) Distribution and abundance 
of early life history stages of the blue crab, Callinectes sapidus, in tidal marsh creeks near Charleston, South Carolina. Estuaries 12:157-168

Mense DJ, Posey MH, West T, Kincheloe K (1995) Settlement of brachyuran postlarvae along the North Carolina coast. Bull Mar Sci 57:793-806

Metcalf KS, van Montfrans J, Lipcius RN, Orth RJ (1995) Settlement indices for blue crabs megalopae in the York River, Virginia: temporal relationships and statistical efficiency. Bull Mar Sci 57:781-792

Morgan SG, Zimmer-Faust RK, Heck KL Jr, Coen LD (1996) Population regulation of blue crabs Callinectes sapidus in the northern Gulf of Mexico: postlarval supply. Mar Ecol Prog Ser 133:73-88

Olmi EJ III (1994) Vertical migration of blue crab Callinectes sapidus megalopae: implications for transport in estuaries. Mar Ecol Prog Ser 113:39-54

Olmi EJ III (1995) Ingress of blue crab megalopae in the York River, Virginia, 1987-1989. Bull Mar Sci 57:753-780

Olmi EJ III, van Montfrans J, Lipcius RN, Orth RJ, Sadler PW (1990) Variation in planktonic availability and settlement of blue crab megalopae in the York River, Virginia. Bull Mar Sci 46:230-243

Perry HM, Eleuterius CK, Trigg CB, Warren JR (1995) Settlement patterns of Callinectes sapidus megalopae in Mississippi Sound: 1991, 1992. Bull Mar Sci 57:821-833

Pietrafesa L, Janowitz GS, Chao TY, Weisber RH, Askari F, Noble E (1986) The physical oceanography of Pamlico Sound. Sea Grant Publication UNC-SG-WP-86-5. North Carolina State University, Raleigh

Rabalais NN, Burditt FR Jr, Coen LD, Cole BE and 5 others (1995) Settlement of Callinectes sapidus megalopae on artificial collectors in four Gulf of Mexico estuaries. Bull Mar Sci 57:855-876

Shanks AL (1983) Surface slicks associated with tidally forced internal waves may transport pelagic larvae of benthic invertebrates and fishes shoreward. Mar Ecol Prog Ser 13: 311-315

Shanks AL (1988) Further support for the hypothesis that internal waves can transport larvae of invertebrates and fish onshore. Fish Bull 86:703-714

Shanks AL (1998) Abundance of post-larval Callinectes sapidus, Penaeus spp., Uca spp., and Libinia spp. collected at an outer coastal site and their cross-shelf transport. Mar Ecol Prog Ser 168:57-69

Shanks AL, Wright WG (1987) Internal-wave-mediated shoreward transport of cyprids, megalopae, and gammarids, and correlated longshore differences in settling rate of intertidal barnacles. J Exp Mar Biol Ecol 114:1-13

Shanks AL, Largier J, Brink L, Brubaker J, Hoff R (2000)

Editorial responsibility: Kenneth Heck (Contributing Editor), Dauphin Island, Alabama, USA
Demonstration of the onshore transport of larval invertebrates by the shoreward movement of an upwelling front. Limnol Oceanogr 45:230-236

Smyth PO (1980) Callinectes (Decapoda: Portunidae) larvae in the Middle Atlantic Bight, 1975-1977. Fish Bull (Wash DC) 78:251-265

Stasko AB (1975) Progress of migrating Atlantic salmon (Salmo salar) along an estuary, observed by ultrasonic tracking. J Fish Biol 7:329-338

Tankersley RA, McKelvey LM, Forward RB Jr (1995) Responses of estuarine crab megalopae to pressure, salinity and light; implications for flood-tide transport. Mar Biol 122:391-400

Tankersley RA, Wieber MG, Sigala MA, Kachurak KA (1998) Migratory behavior of ovigerous blue crabs Callinectes sapidus: evidence for selective tidal-stream transport. Biol Bull (Woods Hole) 195:168-173

Tankersley RA, Welch JM, Forward RB Jr (2002) Settlement time of blue crab (Callinectes sapidus) megalopae during flood-tide transport. Mar Biol 141:863-875

van Montfrans J, Peery CA, Orth RJ (1990) Daily, monthly and annual settlement patterns by Callinectes sapidus and Neopanope sayi megalopae on artificial collectors, deployed in the York River, Virginia: 1985-1988. Bull Mar Sci 46:214-229

van Montfrans J, Epifanio CE, Knott DM, Lipcius RN and 7 others (1995) Settlement of blue crab postlarvae in western North Atlantic estuaries. Bull Mar Sci 57:834-854

Venables WN, Ripley BD (1999) Modern applied statistics with S-Plus. Springer, New York

Walpole RE (1974) Introduction to statistics. Macmillian, New York

Welch JM, Forward RB Jr (2001) Flood tide transport of blue crab, Callinectes sapidus, postlarvae: behavioral responses to salinity and turbulence. Mar Biol 139:911-918

Welch JM, Forward RB Jr, Howd PA (1999) Behavioral responses of blue crab Callinectes sapidus postlarvae to turbulence: implications for selective tidal stream transport. Mar Ecol Prog Ser 179:135-143

Williams AB (1984) Shrimps, lobsters, and crabs of the Atlantic coast of the eastern United States, Maine to Florida. Smithsonian Institutional Press, Washington, DC

Wing SR, Largier JL, Botsford LW, Quinn JF (1995) Settlement and transport of benthic invertebrates in an intermittent upwelling region. Limnol Oceanogr 40:316-329

Wrona AB, Wirgert RG, Bishop TD (1995) Initial report of settlement patterns of brachyuran megalopae at Sapelo Island, Georgia, USA. Bull Mar Sci 57:807-820

Zar JH (1999) Biological statistics. Prentice Hall. Upper Saddle River, NJ

Submitted: April 1, 2003; Accepted: December 17, 2003 Proofs received from author(s): March 1, 2004 